http://economix.fr

Interest margins and bank regulation in Central America and the Caribbean 


\title{
Interest margins and bank regulation in Central America and the Caribbean*
}

\author{
Anthony Birchwood ${ }^{\mathrm{a}}$, Michael Brei ${ }^{\mathrm{b}}$ and Dorian Noel ${ }^{\mathrm{a}}$
}

September 2016

\begin{abstract}
This paper examines empirically the determinants of bank interest margins in Central America and the Caribbean over the period 1998-2014. A particular focus is set on the impact of differences in the regulatory environment and market structure across countries in explaining the interest margins of individual banks. Our results suggest that bank market power, cost inefficiency, credit risk, liquid asset holdings, and interest rate risk increase the margin between loan and deposit rates, while increased income diversification and GDP growth are associated with lower loan-deposit spreads. When considering information on banking regulation, we find strong evidence to support our main hypothesis that improvements in market quality and liberalization have a significant effect on interest margins. More specifically, reductions in entry requirements to banking, higher involvement of foreign banks, and increased financial statement transparency are associated with significant reductions in interest margins.
\end{abstract}

JEL classification: G21; L11; E43.

Keywords: Bank margin; bank spread; Central America; Caribbean.

a University of the West Indies, Trinidad and Tobago, e-mail: anthony.birchwood@sta.uwi.edu \& dorian.noel@sta.uwi.edu

${ }^{b}$ University of the West Indies, Barbados, and EconomiX-University Paris Ouest. Corresponding author, e-mail: michael.brei@uni-bonn.de

\footnotetext{
* We would like to thank Leonardo Gambacorta, Winston Moore, Laurence Scialom, Alfredo Schclareck, Goetz von Peter, Anthony Wood, DeLisle Worrell, and the participants at the annual SALISES (2016) conference in Barbados for helpful comments. All remaining errors are our own.
} 


\section{Introduction}

The banking sector plays a crucial role in the process of economic development and growth, especially in developing countries where financial markets are underdeveloped and banks are the main providers of financial intermediation services. In this paper, we study the determinants of interest rate margin in the banking sectors of the Caribbean and Central America. Interest rate margin is defined as the difference between banks' lending and deposit rates, and along three dimensions it is a key benchmark for a financial system. First, the spread is a performance benchmark providing useful information on the economic cost of the output of the financial sector that is, the cost of financial intermediation. Too large a spread is usually an indication that the banking sector is economically inefficient in performing its intermediation activities of mobilizing investible resources (Demirgüç-Kunt et al., 2004). The eventual long-term economic impact of such a high cost is financial disintermediation and financial exclusion of the less wealthy and vulnerable groups in the society. ${ }^{1}$ Second, the spread is used as a measure of the degree of competitiveness and liquidity of the financial sector. A financial sector with high spreads suggests either noncompetitive pricing by banks, illiquid markets or both. Finally, more recently, the banking sector's spread has also become an important macro-prudential early warning indicator of the soundness of the financial system. ${ }^{2}$ The above-mentioned importance of the spread has made the understanding of its determinants an active area of academic and policy research.

Ho and Saunders (1981) provide the seminal paper on the interest margin. Drawing on an inventory model in the market microstructure literature, the authors attempt to explain the existence of the margin in the United States' banking sector. Similar to dealers' margins in financial markets, they argue that margins in the banking sector reflect the economic costs incurred by risk averse banks in providing immediacy of financial intermediation in the face of transaction uncertainty. In their model, the optimal size of the interest margin is a function of bank competition, transaction size, banks' risk aversion and volatility of interest rates.

Extensions of the Ho and Saunders (1981) model to include other factors are provided by Allen (1988) with a focus on portfolio diversification, McShane and Sharpe (1985) on bank market power, Angbazo (1997) on credit risk, and Maudos and De Guevara (2004) on the importance of operating costs. Empirical evidence for the developed banking systems has confirmed that the interest margin is a positive function of interest rate volatility (Angbazo, 1997; Saunders and Schumacher, 2000; Valverde and Fernández, 2007; Entrop et al., 2015), credit risk (Angbazo, 1997; Maudos and De Guevara, 2004; and Hawtrey and Liang, 2008), and operating costs (Williams, 2007). However, the empirical evidence on the impact of bank market power on interest margins is less clear. Gischer and Jüttner (2003) and Williams (2007) find that countries with more competitive bank markets have smaller margins. However, Demirgüç-Kunt et al. (2004) and Valverde and Fernández (2007) find that the positive relationship between market power and margins breaks down, and can even be negative, once controlling for confounding factors such as institutional development.

\footnotetext{
${ }^{1}$ Overall, these effects will have an impact on increasing the cost of financing real sector activities and undermining economic growth and development (see, for example, Levine (2004)).

${ }^{2}$ Busch and Memmel (2015) note that structural changes in the net interest margin of a bank significantly impact its profitability and are likely to alter the bank's risk taking behavior.
} 
The decline in the margins in the past two decades in developed countries has recently been the focus of empirical research. Lepetit et al. (2008) find that the margin compression is due to increased competitive forces driven, in part, by the strategic shift to transaction-based banking and the lengthening of the financial intermediation chain as a result of shadow banks and securitization. While it seems that competition is an important factor in explaining the decline in the margin, it is not a sufficient condition. Maudos and De Guevara (2004) argue that more open competition rather than heightened competition in the European banking sector has reduced margins. Similarly, Ewijk and Arnold (2014) find that banks' push for growth, not the level of competition per se can better explain the decline in bank margins in the United States.

In comparison, bank interest margins in the Caribbean have also declined while those in Central America have slightly ticked upwards over the period 1998-2014 (see Figure 1). Notwithstanding macroeconomic and market-oriented policies implemented to promote bank competition and financial deepening, overall margins in the Caribbean and Central American remained at a magnitude of more than twice as high as those in the developed countries (see Figure 1). This is an issue that is disconcerting to policymakers and hitherto, has failed to appeal to the research interest of regional academics. Our paper attempts to fill this gap by investigating the determinants of bank margins in the region. More specifically, we empirically examine whether regulatory and market structure differences across the banking sectors in both regions have any influence on banks' margins, notably after controlling for the bank-specific and macroeconomic factors that may drive the spread between lending and deposit rates.

A few papers examine the determinants of interest margins in the Caribbean and Central America. Dick (1999) finds that margins in five Central American countries (Costa Rica, El Salvador, Guatemala, Honduras, and Nicaragua) are largely influenced by operating costs. Similar results are reported in Randall (1998) for countries in the Eastern Caribbean Currency Union (ECCU). Grenade (2007) finds that, in addition to operating costs, market concentration, non-performing loans and the central bank's regulated savings rate also are important determinants of margins in the ECCU. Moore and Craigwell (2002) point to the importance of bank market power in the determination of interest margins in the Englishspeaking Caribbean. Perez (2011) examines bank margins in Belize and finds that market power and non-performing loans largely explain the spread between loan and deposit rates. In a more recent paper, Nassar et al. (2014) also find that operating costs are the most important determinant of interest margins in Honduras. Non-performing loans, liquidity, funding risk and macroeconomic uncertainty also positively impact the margins. Interestingly, the authors find that market concentration negatively influences banks' margin, which is contrary to previously reported results in the literature.

We note, however, that these studies are very similar to those done for developed markets in that they mainly focus on understanding the extent to which bank-specific and a limited set of market structure variables (primarily, market power) influence the margins. How differences in bank regulations across countries impact bank interest margins in the Caribbean and Central America remain unexplored. Moreover, we know of no paper, other than ours, that examines the extent to which financial market reform policies implemented by governments in the region are able to achieve their objectives of having the desired impact on market outcomes. One of which, is reducing the cost of financial intermediation. Our paper's main contribution is that it addresses the policy debate of the efficacy of the 
market reform policies notwithstanding the fact that bank interest margins in the region remain high relative to banks in the developed countries.

Using data on the financial statements of 134 commercial banks (of which 57 are foreign-owned) from 17 countries in Central America and the Caribbean over the period 1998-2014, the present paper examines the determinants of bank interest margins in the region. Our empirical model controls for the impact of the interest rate environment to local economic conditions and bank-specific factors. Consistent with the literature, we find that bank market power, cost inefficiency, credit risk, and interest rate risk increase the margin between loan and deposit rates, while increased income diversification and GDP growth are associated with lower margins. Interestingly, we find a positive relationship between banks' holding of liquid assets and loan-deposit spreads. We argue that although banks benefit from keeping liquidity by being less constrained in the future, their present lending opportunity costs are priced into the margins.

When considering information on financial sector policies across countries, we find strong evidence to support our main hypothesis that improvements in market quality and liberalization have a significant effect on interest margins. More specifically, reductions in entry requirements to banking, higher involvement of foreign banks, and increased financial statement transparency are associated with significant reductions in the interest margin of individual banks. For instance, increasing the disclosure requirements for banks by 20 percent to the level of the developed economies could decrease the average bank margin by 4.8 percent in the long-run, notably after controlling for the aforementioned determinants of interest margins.

The remainder of the paper is organized as follows. Section 2 discusses and reports summary statistics for the sample data. Section 3 describes the empirical model for interest margin. The section also discusses the definitions and measurements of the variables used in parameterizing the empirical model. Section 4 presents the empirical results and Section 5 discusses the robustness checks of the results. Section 6 concludes.

\section{Data methodology and summary statistics}

We obtain bank-level data from BankScope for the period from 1998 to 2014. ${ }^{3}$ Our initial sample covers 492 financial institutions located in 27 jurisdictions in Central America and the Caribbean. Where possible, we gather consolidated financial statements of banks making the assumption that banks manage their entire set of banking activities on a consolidated basis. If no consolidated statement exists, we use the unconsolidated financial statement reported for the bank instead.

Our study focuses on the interest margins of onshore deposit-taking institutions and as a consequence we exclude non-bank entities and offshore banking operations from the sample. ${ }^{4}$ Further, we eliminate banks and countries from the study for which we were unable

\footnotetext{
${ }^{3}$ BankScope is a commercial database of bank-level data maintained by Fitch and the Bureau van Dijk.

${ }^{4}$ We cross-reference the list of financial institutions obtained from BankScope with the registry of licensed banking entities reported on the websites of the various central banks in the region in order to distinguish between onshore deposit-taking entities from the other types of financial firms. The manual selection of banks is important as BankScope classifies many offshore entities as commercial banks.
} 
to obtain relevant information to compute interest margins or the macroeconomic and regulatory variables to parameterise the empirical model (see below for a more detailed data description). ${ }^{5}$ After applying our filters, our final sample covers 134 deposit-taking entities from 17 countries in the Caribbean and Central America. Of the 134 banks, 77 are domestically owned and 57 are subsidiaries of foreign banks. ${ }^{6}$ Out of the 17 countries in our sample 12 are located in the Caribbean (including Belize, Guyana and Suriname) and the other 5 in Central America.

Table 1 reports the list and summary information for the countries in our sample. At the end of 2014, total assets of the 134 banks represented on average 95 percent of GDP. Therefore, our sample is a good representation of the banking sector in the region. The number of banks in our sample is heavily weighted towards the larger economies. This is not surprising since the relationship between the size of a country's banking sector and GDP is positive.

Despite the financial market reforms implemented in these countries in recent years, market entry requirements remained high and reporting transparency relatively low in most countries. Overall for the region the index for bank entry requirements averaged 7.8 out of 8 , which suggests that regulatory requirements for obtaining a banking licence - in the form of legal submissions - are relatively high. ${ }^{7}$ Although it is higher than the world average of 7.6, this figure is comparable to other banking regions (see Table 2). The reporting transparency index, which is graded out of 6, averaged 4.0 and 4.4 in the Caribbean and Central America, respectively, indicating modest disclosure of financial statement information. When compared to the other banking systems, the region displays the one of the lowest levels of reporting transparency in the world. In comparison, the index value is 5.4, 5.2 and 4.9 in North America, Advanced Europe and South America, respectively (see Table 2). There is also evidence of cross-country variation within the region (see Table 1). While Jamaica, Guyana, Costa Rica and the Dominican Republic have the highest financial transparency scores, the lowest levels of reporting transparency are observed in Antigua and Barbuda, Belize, and Saint Vincent and the Grenadines. The market share of foreign-owned banks in the Caribbean is roughly 54 percent and 29 percent in Central America (see Table 2). In the Caribbean, the banking sector has historically been dominated by foreign-owned banks, which is partly due to old colonial institutional ties and the strong presence of Canadian banks. Further, the growth of indigenous banks has fared a lot better in Central America than in the Caribbean.

We compute the interest margin as the difference between the implicit lending rate (ratio of interest income on loans divided by total loans) and the implicit deposit rate (ratio of interest expenses on customer deposits divided by total deposits). Table 3 provides

\footnotetext{
${ }^{5}$ Several countries are not included in the database on banking regulation (Bahamas, Barbados, Bermuda, Cuba, Curacao, Haiti), others lack sufficient information to calculate the macroeconomic control variables (Cayman Islands, El Salvador), or they do not have sufficient BankScope information on the various bank-specific indicators (British Virgin Islands, Dominica).

${ }^{6}$ We note that the sample of banks does not cover the entire banking systems especially in the Caribbean because some large banks in this region are not covered in BankScope.

${ }^{7}$ The index considers 8 categories of legal submissions: draft by-laws, organization chart, 3-year financial projections, financial information on shareholders, experience of future directors, experience of future managers, sources of funds in capitalization of new bank, and intended market differentiation of new bank.
} 
summary statistics on the implicit interest rates, margins and other performance variables for the banking sectors in the sampled countries. Over the period 1998-2014, most countries experienced average loan rates in the double-digit range but single-digit deposit rates. In 5 of the 17 countries, the interest margins averaged more than 10 percent over the period. The interest rates and margins were the highest in Jamaica, a reflection of the 1998 banking crisis, subsequent economic decline and surge in inflation. Costa Rican banks, on the other hand, operated with the lowest interest margins. This result may be a combination of the higher deposit rates due to increased competition in the deposit market and the concerted attempts by the banking regulator to reduce bank margins.

In Figure 1 (right-side), we provide a comparison of the margins in the Caribbean and Central America to those in the advanced economies. Although starting from different levels, interest margins in the Caribbean and the advanced economies have declined over the sample period, while those in Central America have fluctuated around an average of 6 percent. The dispersion of bank margins across banks was the highest in Central America compared to the other two country groupings, as evidenced by the wider $25^{\text {th }}$ and $75^{\text {th }}$ percentile bands. Despite the macroeconomic and market-oriented policies implemented to promote bank competition and financial deepening, overall margins in the Caribbean and Central America were approximately twice as high as those in the advanced economies. More specifically, over the period 1998-2014 the interest margin averaged roughly 3.7 percent in the advanced economies, 6.3 percent in Central America and 9.0 percent in the Caribbean.

Figure 1 (left-side) also shows the breakdown of the margin into loan and deposit rates plotted against the rate of inflation. A casual inspection of the plot reveals that both deposit and loan rates in the advanced economies were more responsive to inflation rate movements than in the Caribbean and Central America. In the Caribbean, deposit rates were downwards-flexible but upwards-sticky with respect to the changes in the rate of inflation. Similar deposit pricing behaviour has been observed by Driscoll and Judson (2013) for the US banking industry. Loan rates, however, have been much more responsive to changes in inflation rates. It seems that the variability of the margin, especially in the Caribbean, has more to do with banks' ability to get depositors to fund a larger portion of the margin than borrowers.

We have seen that bank margins in the Caribbean and Central America were roughly double the figure reported for advanced economies. In Table 3, we report other bankspecific factors that are widely cited in the literature to influence interest margins. One can observe that important pricing variables such as operating costs (proxy for cost efficiency), non-performing loans (proxy for credit risk) and liquid assets (proxy for liquidity risk) were, on average, roughly 1.5-2 times higher in the Caribbean and Central America compared to the advanced economies. The mere fact that margins are high does not necessarily mean that this can be entirely explained by bank-specific factors. Other factors such as inflation, economic uncertainty and market power have also been found to influence bank margins.

Figure 2 shows yearly averages of banks' market power, cost efficiency, credit risk, liquidity risk, non-interest income and interest rate volatility for the region. The most striking feature is that the evolution of the various indicators in the Caribbean and Central America significantly diverge after the onset of the global financial crisis in 2008. In the Caribbean, the global financial crisis has led to increases in operating costs (fall in operating efficiency), credit risk (higher ratio of non-performing loans), liquidity risk (higher liquid asset ratio), and 
interest rate risk (higher interest rate volatility). These cost increases appeared to be partly funded by increases in non-interest income in the Caribbean (see Figure 2) and only partially by higher margins (see Figure 1). In contrast, patterns in Central America were more or less the opposite. Further, bank market power tended to be higher in the Caribbean compared to Central America. While bank market power has decreased in recent years in Central America, in the Caribbean it has increased (see Figure 2). This suggests that the banking sectors in the Caribbean is more concentrated than in Central America, which is certainly related to the limited size of the small island economies of the Caribbean.

In the ensuing section, we investigate whether and which bank-specific, macroeconomic, regulatory and market structure factors have been the main drivers of the bank margins in the two regions.

\section{Empirical Model}

In this section, we present an econometric framework that is designed to investigate the causal relationship of the different explanatory factors and bank margins in the region. We treat the apparent heterogeneity in our data by controlling for the differences in the macroeconomic environment and other country-specific factors that may influence the margin. The explanatory variables, which we discuss in more detail below, are widely cited factors in the literature (see amongst others, McShane and Sharpe, 1985; Angbazo, 1997; Brock and Rojas Suarez, 2000; Demirgüç-Kunt et al., 2004; Gischer and Jüttner, 2003; Martinez Peria and Mody, 2004; Maudos and De Guevara, 2004; Williams, 2007; Valverde and Fernández, 2007; Williams, 2007). We note that a number of countries in the region have implemented market-reform policies aimed at increasing market quality and competition in the banking sector. Hence, we examine whether these policies have achieved their intended outcomes, one of which is to lower the cost of financial intermediation. More specifically, we introduce another set of variables relating to bank regulation and market structure into our model to formally test whether differences in bank regulation across countries have any impact on bank margins.

Our econometric model takes the form of a dynamic panel regression:

$$
Y_{i j t}=\alpha_{0}+\alpha_{i}+\alpha_{1} Y_{i j t-1}+\beta X_{i j t}+\gamma M_{j t}+\delta R_{j t}+\varepsilon_{i j t},
$$

where $Y_{i j t}$ denotes the interest margin of bank $i$ located in country $j$ in year $t, X_{i j t}$ a vector of bank-specific characteristics, $M_{j t}$ a vector of macroeconomic control variables, and $R_{j t}$ a vector of regulatory and market structure variables. We include bank fixed-effects $\alpha_{i}$ to account for time-invariant and unobserved differences in the margins across banks and countries. We estimate a dynamic specification by including the interest margin of the previous year to account for the possibility that banks may smooth their interest margins over time.

As mentioned previously, the interest margin is calculated as the difference between the implicit lending rate (ratio of interest income on loans over total loans) and the implicit deposit rate (ratio of interest expenses on customer deposits over total deposits). In the robustness checks below, we re-estimate the regression using a measure of the margin that includes net fees and commissions.

The vector $X_{i j t}$ includes bank-specific factors of interest margins that have been highlighted in the empirical literature as important determinants of bank spreads, notably 
the Lerner index, operating costs, non-performing loans, liquid asset holdings, non-interest income, loan-deposit ratio and bank capital. We instrument the bank-specific characteristics by their values one year ahead $(t-1)$ in order to mitigate any possible endogeneity problem we may have in our model specification.

While most of the control variables are calculated using direct information provided by BankScope, we estimate bank market power by an auxiliary regression to obtain the Lerner index. The Lerner Index is hereby computed as follows (Lerner, 1934; Hainz et al., 2013):

$$
L I_{i t}=\frac{P_{i t}-M C_{i t}}{P_{i t}}
$$

where $P_{i t}$ is the price of banking outputs for bank $i$ at time $t$, and $M C_{i t}$ the marginal cost for bank $i$ at time $t$. The price for banking outputs is measured by the ratio of total bank revenues (gross dividend and interest income plus total non-interest operating income) to total assets. Marginal costs are calculated via the estimation of the following trans-log cost function:

$$
\begin{aligned}
\ln \left(T C_{i t}\right)=\alpha_{0} & +\alpha_{1} \ln \left(Q_{i t}\right)+\frac{1}{2} \alpha_{2} \ln \left(Q_{i t}\right)^{2}+\sum_{n=1}^{3} \beta_{n} \ln \left(w_{\text {int }}\right)+\sum_{m=1}^{3} \sum_{n=1}^{3} \beta_{m n} \ln \left(w_{\text {imt }} w_{\text {int }}\right) \\
& +\sum_{n=1}^{3} \gamma_{n} \ln \left(Q_{\text {int }}\right) \ln \left(w_{\text {int }}\right)+\varepsilon_{i t}
\end{aligned}
$$

where marginal costs are obtained by

$$
M C_{i t}=\frac{T C_{i t}}{Q_{i t}}\left(\alpha_{1}+\alpha_{2} \ln \left(Q_{i t}\right)+\sum_{n=1}^{3} \gamma_{n} \ln \left(w_{i n t}\right)\right)
$$

Total costs $T C_{i t}$ are measured by the sum of personnel expenses, other non-interest and interest expenses, output $Q_{i t}$ by total assets, and $w_{\text {in }}$ are three input prices (i.e., for labour, capital and funding). The price of labour is hereby measured by the ratio of personnel expenses to total assets, the price of physical capital by the ratio of other non-interest expenses to fixed assets, and the price for borrowed funds is measured by the ratio of interest expenses to total funds. Where the Lerner index is close to one it implies a higher degree of bank market power. We expect that banks operating in a market with high degree of market concentration will charge higher margins than those operating in markets where market power is more dispersed. In other words, the greater the intensity of competition amongst banks, the lower bank margins (McShane and Sharpe, 1985; Gischer and Jüttner, 2003; Williams, 2007; Demirgüç-Kunt et al., 2004; Valverde and Fernández, 2007; Leuvensteijn et al., 2013; Boutin-Dufresne et al., 2015).

We measure operating costs as the ratio of the sum of costs related to wages, social security, pension, administration, occupancy, software, and audit or professional fees (total non-interest expenses) divided by total assets. We expect banks that provide their intermediation services at higher administrative costs than other banks will charge higher loan rates and are also likely to pay-out lower deposit rates. This implies that banks with higher operating costs are expected to have higher interest margins than banks with lower operating costs (Brock and Rojas Suarez, 2000; Martinez Peria and Mody, 2004; Maudos and 
De Guevara, 2004; Williams, 2007).

The non-performing loan ratio is calculated as non-performing loans divided by total loans. We expect the non-performing loan ratio to be positively related with bank interest margins because the expected loss due to loan default is an important risk factor in determining the price of bank credits. Therefore, banks with higher risk in their credit books are likely to adjust upwards their interest margins to cover expected losses arising from default by more than banks with lower credit risk (Angbazo, 1997; Brock and Rojas Suarez, 2000; Martinez Peria and Mody, 2004).

Similarly, we expect banks with higher liquidity risk will operate with higher margins compared to banks with lower liquidity risk. This is due to the fact that the holding of liquid assets by banks to meet either regulatory requirements or depositors' withdrawals imposes a higher opportunity costs on their funds. As a result, this cost will be priced into the setting of interest margins (Kashyap and Stein, 1995). We measure liquidity risk as the ratio of total liquid assets (cash and due from banks, including reserve requirements at the central bank, and loans and advances to banks) to total assets. If holding liquid assets imposes an opportunity cost in line with the view that banks could transform their liquid assets into more profitable customer loans (Kashyap and Stein, 1995), then it could be that banks pass on some of these opportunity costs to borrowers and depositors. Therefore we expect a positive relationship between bank margins and the ratio of liquid assets to total assets.

Banks' liquidity risk can also be proxied by the loan-to-deposit ratio (see Park et al., 2015). A high ratio suggests that banks rely to a larger extent on the wholesale market or on equity to fund their credit books. Equity and wholesale funds are usually more costly than (insured) deposits. According to this argument, the margins would tend to be higher for banks with higher loan-to-deposit ratios. However, a low ratio means that banks are holding higher liquidity on the asset side, which raises the opportunity argument discussed above. So a low ratio can also result in high margins. The expected sign of the loan-to-deposit ratio is therefore undetermined.

Income diversification is measured by non-interest income as a proportion of total assets. The literature is not clear as to the relationship between the degree of banks' income diversification and interest margins. Vander Vennet (2002) and Elsas et al. (2010) find a positive relationship between the two variables. They note that higher income diversification is associated with higher bank profitability and reduced volatility of earnings. Banks may respond by passing on some of the benefits to customers in the form of lower interest margins. In contrast, Jiménez and Saurina (2004) and Demirgüç-Kunt and Huizinga (2010) argue that banks with more diversified fields of activities have greater income risks which could be due to lack of managerial experience and/or higher volatility of earnings associated with non-interest revenue streams. If this holds, then interest margins might be negatively related to the degree of income diversification. We are also not certain as to the relationship between bank margins and the degree of diversification of banks' income streams for the markets we study. We note, however, that for the sampled banking sectors non-interest income has been the fastest growing component of banks' income in recent years (Craigwell and Maxwell, 2005; Bailey-Tapper, 2010).

Finally, we include the ratio of bank equity to total assets. The relationship between capital and the interest margin can be positive or negative. Higher capital ratios give banks a higher loss-absorbing capacity and, hence, reduce the probability of default. Brock and Rojaz 
Suarez (2000) argue that poorly capitalized (more risky) banks can have the incentive to reduce loan rates and raise deposit rates in order to capture greater market share. Moreover, one can also argue that if equity is more costly than external funds, banks are likely to charge higher margins to fund their equity positions. These arguments imply that better capitalized banks operate with higher margins. Similar prediction is provided in Williams (2007) for the Australian banking sector. The prediction is also consistent with Ho and Saunders (1981). However, Gambacorta and Shin (2016) observe that higher ratios of equity to assets are associated with lower funding costs of banks in the advanced economies. If these cost advantages are priced into the margins, we should observe a negative relation between bank capital and the interest margin.

In addition to the bank-specific factors, macroeconomic factors also are likely to influence bank margins by affecting the interest rate environment and credit conditions. As a result, we include in the vector $M_{j t}$, real GDP growth, CPI inflation, and the monthly volatility of the market interest rate as proxies for economic conditions. ${ }^{8}$ Kashyap et al. (1993) argue that better economic conditions increase the expected net present value of investment projects, improve the creditworthiness of borrowers and drive credit demand. This would imply that interest margins are likely to narrow as economic conditions improve. In addition to its impact on the present value of investments, inflation may also have a secondary effect of increasing economic uncertainty and information asymmetries across borrowers and lenders (Huybens and Smith, 1999). Therefore, risk averse banks may charge higher margins to compensate for the risks associated with asymmetric information. Martinez Peria and Mody (2004) note that inflation may also have an asymmetric impact on deposit and loan rates suggesting that bank margins may vary positively with inflation.

The volatility of the monthly market interest rate is intended to control for uncertainty banks' face in their lending business. The higher the uncertainty about interest rates in the future, the higher will be the interest margin of banks (Angbazo, 1997; Saunders and Schumacher, 2000; Valverde and Fernández, 2007; Entrop et al., 2015). According to Hellwig (1994), banks face a reinvestment risk, the risk of having to roll-over maturing contracts at uncertain rates in the future, and a valuation risk, the risk associated with changes in the value of banks' banking book due to changes in interest rates. Both risks are likely to increase bank margins.

We include a vector $R_{j t}$ of regulatory and market quality variables to examine the impact of cross-country differences in financial sector policies on interest margins. As mentioned earlier, the banking systems in the Caribbean and Central America have undergone significant changes due to market reform policies adopted by the respective governments to improve the efficiency and price competitiveness of banks. To capture regulatory differences across countries, we include in vector $R_{j t}$ bank entry requirements,

\footnotetext{
${ }^{8}$ We use the IMF-IFS database as primary source for the macroeconomic variables. Real GDP growth is calculated by the annual growth rate of the real GDP index (series NGDP.R.IX) and inflation by the annual growth rate of the CPI index for all items (PCPI.IX). In very few cases (mainly Guyana), the series have been complemented with data from the International Labor Organization (ILO) and Moody's Statistical Handbook. The volatility of the interest rate has been proxied by the standard deviation of the monthly lending rate (FILR.PA), because this interest rate series has the largest coverage in the IMF-IFS database for our sample of countries. The standard deviation has been calculated using a window of 24 months.
} 
reporting transparency, and the foreign bank share of banking assets. ${ }^{9}$ The foreign bank share to a certain extent is related to bank entry requirements but is a much boarder measure of openness of the banking sector. Domestic entry requirements may be low but, at the same time, foreign entry requirements may still be high.

Regulatory entry requirements are likely to have an impact on competition and therewith on the intermediation margin. Besanko and Thakor (1992) argue that relaxations of entry restrictions into banking can improve the welfare of borrowers and savers at the expense of bank stockholders. They predict that margins will be smaller in banking sectors with lower entry requirements through a combination of lower loan rates and higher deposit rates (see also Demirgüç-Kunt et al., 2013). As Brock and Rojaz Suarez (2000) argue, however, an overly permissive attitude towards the entry of new banks can pose a threat to financial system stability, especially, when many or large entrants compete aggressively with the existing banks for costumers by lowering loan rates and increasing deposit rates to levels that are unsustainable.

We also include the foreign bank share of banking sector assets to investigate whether banks in more open banking sectors operate with lower interest margins. The empirical literature tends to find a positive impact of foreign bank entry on bank efficiency stemming from technology transfer, increased competition, and the mitigation of connected lending (Claessens et al., 2001; Clarke et al., 2003; Giannetti and Ongena, 2009, 2012). The evidence on the impact of bank ownership on the interest margin is however mixed. Martinez Peria and Mody (2004) find that newly established foreign banks in Latin America operated with lower margins compared to domestic banks, while Claessens et al. (2001) report that foreign banks had higher margins.

Another important aspect of banking sector regulation, albeit much less noted in the literature, is the potential link between bank disclosure and reporting requirements and the interest margin. By increasing information asymmetries between bank insiders and outsiders, low financial transparency can have a negative effect on private sector monitoring of banks and therewith on their pricing policies. If such informational barriers weaken the ability of private investors to exert effective monitoring and governance of banks, we should observe limited market discipline in less transparent banking systems and higher levels of incentive distortions. Barth et al. (2013b) document that bank efficiency can be enhanced through improvements in market-based monitoring of banks in terms of higher reporting transparency. This is in line with the observations made by Honohan and Beck (2007) who argue that transparent financial statements are crucial for reducing screening and monitoring costs for lenders and therewith having the potential of increasing the efficiency of resource allocation. According to these views, we should observe higher interest margins in more opaque bank markets.

\footnotetext{
${ }^{9}$ The indicators are taken from Barth et al. (2013a). Given that the regulatory indicators are collected since 1999 on a 4-year frequency, we carried forward the values of the latest survey until the release of the subsequent survey. For the year 1998, we assumed that the indicators are equal to those observed in 1999.
} 


\section{Empirical Results}

We estimate three separate models for bank margins. The first includes only bankspecific factors, while the second includes in addition the macroeconomic variables previously discussed. The third incorporates all three sets of factors: bank-specific, macroeconomic, and regulatory/market quality. The summary statistics for the regression variables are shown in Table 4, and the regression results are reported in Table 5 . We also compute the implied elasticities for the explanatory variables estimated for a 10 percent increase in the mean of the respective variable (see Table 6).

Across all model specifications, we find that bank margins are positively correlated over time. The result confirms our dynamic model specification. Further, the Hansen test validates the instruments used in all model specifications, given that we cannot reject the null hypothesis that the instruments can be considered exogenous. The results indicate that the significant of the variables in models 1 and 2, respectively, are also similar to those in model 3. Without any loss of generality, therefore, the ensuing discussion will focus on the estimated results for model 3 (full model specification), shown in column 3 of Table 5.

The regression results show that market power, operating costs and non-performing loans have a significant positive impact on bank margins. This confirms our a priori expectation that banks operating in monopolistic market environments, with high operating costs and credit risks tend to have higher margins. Less intense competition across banks is thus associated with higher intermediation margins in the region in line with the view that banks take advantage of their market power at the expense of borrowers and depositors. Moreover, banks with less efficient cost structures are more likely to price these costs into their margins. Also as credit risks increase, banks are likely to increase their margins to cover higher expected losses in their credit portfolios. Similar results are reported in Brock and Rojas Suarez (2000) and Martinez Peria and Mody (2004) for a number of banking sectors in Latin America.

Interestingly, we find a positive relationship between banks' holding of liquid assets and interest margins. We argue that although banks benefit from keeping liquidity by being less constrained in the future, their present lending opportunity costs in the form of foregone interest earnings are priced into the margins. The result is important from a Basel banking regulation perspective. Basel III requires banks to hold higher levels of liquidity to reduce the likelihood of liquidity crises. These stricter liquidity requirements may come at a higher cost to the banking sector. As our results suggest these increased regulatory costs are likely to be borne by banks' customers through higher margins on products and services.

We find that income diversification of bank earnings has had a negative impact on interest margins in the Caribbean and Central America. Lepetit et al. (2008) report similar results for the European bank market. The result suggests that banks with higher levels of non-traditional income revenues are in the position to reduce interest margins in the traditional banking business. Lepetit et al. (2008) argue, however, that banks in Europe strategically reduce margins in traditional banking lines in order to grow their transactionbased fee business. Our findings for the bank markets of Caribbean and Central America are perhaps consistent with these arguments. The results discussed so far are not only statistically significant but economically as well. Most responsive is the margin to changes in operating costs, market power and liquid asset holdings. More specifically, in response to a 
10 percent increase in operating costs, the interest margin increases by 4.4 percent in the short-term and 9.7 percent in the long-term (see Table 6). We also find that the short-run elasticity of bank margins to market power (proxied by the Lerner index) is roughly 2.3 percent and that for liquid assets holdings is 1.7 percent.

Our findings for the impact of the macroeconomic environment on bank margins are largely consistent with those in the literature. Increased economic growth reduces bank margins by improving credit market conditions. The result that inflation does not affect the interest margin significantly is similar to the results obtained by Martinez Peria and Mody (2004) for Latin American banks. Further, higher levels of volatility in the market interest rate results in higher bank margins as banks adjust their rate prices to cover the increased uncertainty in the interest rate rate environment. Hellwig (1994) and Entrop et al. (2015) report similar findings for the banking sectors in Europe.

Finally, we find strong evidence that differences in the regulatory environment and market structure across countries influence interest margins and their variability within banks. In particular, we find that in countries with more stringent bank entry requirements and low foreign bank presence, banks appear to operate with higher interest margins. This finding is consistent with the competition-margin nexus discussed above. In line with Besanko and Thakor (1992), banks with a monopolistic market position earn higher margins than those operating in more competitive environments. The short-and long-run margin elasticities for a 10 percent increase in bank entry requirements are 2.8 and 6.2 percent, respectively. This suggests that bank customers in the region can benefit from a lowering of bank entry requirements.

We also find that financial statement transparency is associated with lower bank margins in both markets. This is an important finding of our study as it suggests that information asymmetries can undermine competitive market outcomes. In markets where banks are compelled to publish reliable, comprehensive and consolidated information on the full range of bank activities and risk management procedures, the private sector can exert more effective monitoring of banks and therewith help improving the functioning of financial intermediation. Our results show that a 10 percent increase in bank transparency decreases bank margins, on average, by 2.4 percent over the long-run. In the context of the Caribbean and Central America, which have low ranking for financial transparency (see Table 2), this finding is particularly important from a policy perspective. It suggests that policy makers can influence bank margins by increasing banking transparency rather than taking a more direct approach of controlling interest rate pricing, which may distort efficient market outcomes. For instance, increasing the disclosure requirements for banks by 20 percent to the level of the developed economies could decrease the average bank margin by 4.8 percent in the long-run.

\section{Robustness Tests}

In this section, we discuss several tests applied to assess the robustness of our regression results. First, we test to see whether the results are sensitive to the definition of the margin used. We thus re-estimate the models using a measure of the margin that includes net non-interest fees and commissions. These results are reported in the last three columns of Table 5 . We find that the results are materially very similar to those reported 
above both in terms of magnitude and significance. Moreover, market competition, entry requirements and transparency are still significant determinants of bank margins. The only notable exception is that real GDP is no longer significant at any conventional confidence levels (with a $p$-value of approximately 15 percent).

Second, we test whether differences in bank margins may reflect differences in institutional quality in that banking regulations in countries with poor institutional quality may be skewed towards the protection of banks' power (Acemoglu et al., 2001 and Demirgüç-Kunt et al., 2004), or by pushing banks to engage in costly credit appraisals and monitoring (Honohan and Beck, 2007; Boutin-Dufresne et al., 2015). To control for institutional quality, we include in our model an index of economic freedom. The index compiled by the Heritage Foundation is an average score that assesses the quality of rule of law, regulatory efficiency, open markets, and the extent to which governments intervene in the economy. ${ }^{10}$ The estimation results are largely similar for the definition of the margin without net fees and with net fees included. Thus, for brevity, we only report the results for the margin with fees in Table 7. As can be seen in the table, our main results are largely unaffected after controlling for economic freedom (see column 7).

Third, we test whether bank size plays a role in determining intermediation margins in the region, as smaller banks that are likely to target the lower end of the market tend to incur cost and efficiency disadvantages and to operate with higher margins (Beck and Hesse, 2009). It appears, however, that our previous control variables such as market power and cost efficiency capture the effects on margins bank size may have, as evidenced by the fact that the results are robust to the inclusion of bank size (logarithm of assets), which itself is insignificant (see column 8).

Fourth, we introduce a bank-specific dummy variable for foreign banks to our model to test whether the subsidiaries of international banks operated with lower interest margins than domestic banks. ${ }^{11}$ The results suggest that margins of foreign banks are higher than those of comparable domestic banks (see column 9). This result is consistent with Claessens et al. (2001) who find that foreign banks tend to have higher margins. As Brock and Rojaz Suarez (2000) argue foreign banks are likely to incur higher information costs of monitoring domestic borrowers than domestic banks. Nevertheless, our earlier reported results of the negative influence of the foreign bank share on margins still holds. This is an interesting result in that although foreign banks, on average, have higher margins than domestic banks with similar characteristics, their market presence is important to keeping margin levels competitive in the banking sector.

Fifth, we include interaction terms between the regulatory indicators and a dummy variable for Caribbean countries to see whether the effect of regulatory factors and market structure on bank margins in the Caribbean is different from that in Central America. Our main results reported above are robust to this modification and suggest that bank regulation has similar effects in both regions (see column 10). This confirms our previous findings that

\footnotetext{
${ }^{10}$ Note that Anguilla, Antigua and Barbuda, Aruba, Grenada, and St. Kitts \& Nevis are not covered in this database and that we had to drop the banks from these countries in this robustness test.

${ }^{11}$ To construct the foreign bank dummy variable, we have used the database provided by Claessens and Van Horen (2015) as primary source. When information on particular banks was missing, we used information on the global ultimate owner provided by BankScope.
} 
in countries with more stringent bank entry requirements, more opaque banking systems, and low foreign bank presence, interest margins are higher.

Finally, we decompose the interest margin into its loan and deposit rate components and re-estimate our model to examine whether the variables' impacts are similar for both components or not. Moreover, the analysis will allow us to determine the transmission mechanism of each variable to the interest margin. The re-estimated model results are reported in the last two columns of Table 7 . The results reveal that real GDP, inflation and foreign bank share influence both loan and deposit rates in the same direction but at varying degrees. Not surprisingly, real GDP has a negative effect on both rates, while the inflation effect is positive. Interestingly, we find that the foreign bank share not only has a negative influence on loan rates but also the deposit rates. While it is understandable to expect that an increase in the foreign bank share will reduce loan rates, a reduction in deposit rates is more difficult to explain. It could be that banks responded to the increased foreign bank competition by reducing both loan and deposit rates so as to keep margin levels relatively stable.

We find that bank market power increases loan rates but lowers deposit rates. Therefore, banks with market power earn monopolistic revenue from both depositors and borrowers. The positive impact of banks' operating inefficiencies and bank entry requirements on the interest margins transmit through higher loan rates. Further, income diversification and bank transparency negatively impact bank margins but it is only due to a reduction in loan rates. With respect to the finding that income diversification is negatively associated with lending rates, the result seems consistent with the argument that banks reduce lending rates to attract customers in order to build their transaction-based fee business (Lepetit et al., 2008). Another interesting finding is that banks in transparent markets operate with lower lending rates but not with higher deposit rates, which could be explained by both the increased price competitiveness in more transparent banking sectors, possibly related to market discipline effects, and regulated deposit rates that are present in a number of countries in our sample. 


\section{Conclusions}

This paper extends the empirical literature on the interest margin model of Ho and Saunders (1981) to include a richer set of variables relating to the regulatory environment, market quality and market structure. We apply our model to data on individual banks that operate in the Caribbean and Central America. One of the main contributions of the paper is that it assesses the efficacy of the market reform policies adopted by the governments in the region to improve, inter alia, price competitiveness of the banking sector.

Our results suggest that bank market power, cost inefficiency, credit risk, liquid asset holdings, and interest rate risk increase the margin between loan and deposit rates, while increased income diversification and GDP growth are associated with lower margins. We find strong evidence to support our main hypothesis that improvements in market quality and liberalization have had a significant impact on bank margins. More specifically, lowering of the entry requirements to banking, higher involvement of foreign banks, and increased financial statement transparency have led to a reduction in bank margins. From a policy perspective, our findings suggest that policy makers can further influence bank margins by continuing the policies of improving market quality rather than taking a more direct approach of controlling interest rate pricing, which may distort efficient market outcomes. For example, increasing the disclosure requirements for banks by 20 percent to the level of the developed economies could decrease the average bank margin by 4.8 percent in the long-run. 


\section{References}

Allen, L., A. Saunders and G.F. Udell. 1991. "The pricing of retail deposits: Concentration and information". Journal of Financial Intermediation. Vol. 1: 335-361.

Angbazo, L. 1997. "Commercial bank net interest margins, default risk, interest-rate risk, and off-balance sheet banking". Journal of Banking and Finance. Vol. 21(1): 55-87.

Arellano, M. and O. Bover. 1995. "Another look at the instrumental variable estimation of error-components models". Journal of Econometrics. Vol. 68(1), 29-51.

Bailey-Tapper, S. 2010. "Non-interest income, financial performance and the macroeconomy: Evidence om Jamaica Panel Data". Staff Working Papers. Bank of Jamaica: Kingston.

Barth, J.R., G. Caprio Jr and R. Levine. 2013a. "Bank regulation and supervision in 180 countries from 1999 to 2011". Journal of Financial Economic Policy. Vol. 5(2): 111 - 219.

Barth, J.R., C. Lin, Y. Mac, J. Seade and F.M. Song. 2013b. "Do bank regulation, supervision and monitoring enhance or impede bank efficiency?". Journal of Banking and Finance. Vol. 37: 2879-2892

Beck, T. and H. Hesse. 2009. "Why are spreads so high in Uganda?", Journal of Development Economics. Vol. 88: 192-204.

Besanko, D. and A.V. Thakor. 1992. "Banking deregulation: Allocational consequences of relaxing entry barriers". Journal of Banking and Finance. Vol. 16(1): 909-932.

Boutin-Dufresne, F., Williams, O., and T.A. Zawisza. 2015. "Banking sector efficiency in SubSaharan Africa". Journal of African Economies. Vol. 24: 325-51.

Brei, M. and L. Gambacorta. 2016. "Are bank capital ratios pro-cyclical? New evidence and perspectives". Economic Policy. Vol. 31: 357-403.

Brock, P. and S. Rojas Suarez. 2000. "Understanding the behavior of bank spreads in Latin America". Journal of Development Economics. Vol. 63: 113-134.

Busch, R. and C. Memmel. 2015. "Banks' net interest margin and the level of interest rates". Discussion Paper, no. 16/2015. Deutsche Bundesbank: Frankfurt am Main.

Claessens, S., A. Demirgüç-Kunt and H. Huizinga. 2001. "How does foreign bank entry affect domestic banking markets". Journal of Banking and Finance. Vol. 25(5), 891-911.

Claessens, S. and N. Van Horen, 2015, "The impact of the global financial crisis on banking globalization". IMF Economic Review. Vol. 63(4): 868-918. 
Clarke, G., M.S. Martinez Peria and S. Sanchez. 2003. "Foreign bank entry: Experience, implications for developing countries, and agenda for further research". World Bank Reserach Observer. Vol. 18 (1): 25-59.

Craigwell, R. and C. Maxwell. 2005. "Non-interest Income and financial performance at commercial banks in the Caribbean". Staff Working Papers. Central Bank of Barbados: Bridgetown.

Demirgüç-Kunt, A. and H. Huizinga. 2010. "Bank activity and funding strategies: The impact on risk and returns". Journal of Financial Economics. Vol. 98: 626-650.

Demirgüç-Kunt, A., L. Laeven and R. Levine. 2004. "Regulations, market structure, institutions, and the cost of financial intermediation". Journal of Money, Credit, and Banking, Vol. 36(3): 593-622.

Dick, A. 1999. "Banking spreads in Central America: Evolution, structure and behavior". Development Discussion Paper, no. 694. Harvard Institute for International Development. Harvard University: Harvard, MA.

Driscoll, J.C. and R.A. Judson. 2013. "Sticky deposit rates". Finance and Economic Discussion Series. Federal Reserve Board.

Elsas, R., Hackethal, A. and M. Holzhäuser. 2010. "The anatomy of bank diversification". Journal of Banking and Finance, Vol. 34: 1274-1287.

Entrop, O., Memmel, C., Ruprecht, B. and M. Wilkens. 2015. "Determinants of bank interest margins: Impact of maturity transformation", Journal of Banking and Finance, Vol. 54: 1-19.

Ewijk, E. and I. Arnold. 2014. "How bank business models drive interest margins: Evidence from U.S. bank-level data". The European Journal of Finance, Vol. 20(10): 850-873.

Gambacorta, L. and H.S. Shin. 2016: "Why bank capital matters for monetary policy". BIS Working Papers 558.

Giannetti, M. and S. Ongena. 2009. "Financial integration and firm performance: Evidence from foreign bank entry in emerging markets". Review of Finance, Vol. 13(2), 181-223.

Giannetti, M. and S. Ongena. 2012. Lending by example: Direct and indirect effects of foreign banks in emerging markets. Journal of International Economics, Vol. 86(1), 167-180.

Gischer, H. and J. Jüttner. 2003. "Global competition, fee income and interest rate margins of banks". Kredit und Kapital. Vol. 36(3): 368-394.

Grenade, K. 2007. "Determinants of commercial banks interest rate spreads: Some empirical evidence from the Eastern Caribbean Currency Union." ECCB Staff Research Paper, WP/07/01. ECCB: St. Kitts. 
Hainz, C., L. Weill, and C.J. Godlewski. 2013. "Bank competition and collateral: Theory and evidence". Journal of Financial Services Research, Vol. 44, no. 2: 131-148

Hawtrey, K. and H. Liang. 2008. "Bank interest margins in OECD countries". North American Journal of Economics and Finance. Vol. 19: 249-260.

Hellwig, M.F. 1994. "Liquidity provision, banking, and the allocation of interest rate risk". European Economic Review, Vol. 38(7): 1363-1389.

Ho, T., and A. Saunders. 1981. "The determinants of bank interest margins: Theory and empirical evidence". Journal of Financial and Quantitative Analysis, Vol. 16(4): 581-600.

Honohan, P., and T. Beck. 2007. "Making Finance Work for Africa". World Bank Publications. No. 6626.

Huybens, E. and B. Smith. 1999. "Inflation, financial markets, and long-run real activity", Journal of Monetary Economics, Vol. 43: 283-315.

Jiménez, G. and J. Saurina. 2004. "Collateral, type of lender and relationship banking as determinants of credit risk". Journal of Banking and Finance Vol. 28, 2191-2212.

Kashyap, A., J. Stein and D. Wilcox. 1993. "Monetary policy and credit conditions: Evidence from the composition of external finance". American Economic Review Vol. 83, 78-98.

Kashyap, A.K. and J.C. Stein. 1995. "The impact of monetary policy on bank balance sheets". Carnegie-Rochester Conference Series on Public Policy. Vol. 42: 151-195.

Lepetit, L., E. Nys, P. Rous and A. Tarazi. 2008. "The expansion of services in European Banking: Implications for loan pricing and interest margins". Journal of Banking and Finance. Vol. 32(11): $2325-2335$.

Lerner, A.P. 1934. "The concept of monopoly and the measurement of monopoly power". The Review of Economic Studies. Vol. 1(3): 157-175.

Leuvensteijn, M., C.K. Sorensen, J.A. Bikker and A. Van Rixtel. 2013. "Impact of bank competition on the interest rate pass-through in the Euro Area". Applied Economics. Vol. 45(11): 1359-1380.

Levine, R. 2004. "Finance and growth: Theory and evidence". NBER Working Paper 10766.

Moore, W. and R. Craigwell. 2002. "Market power and interest spreads in the Caribbean". International Review of Applied Economics. Vol. 16: 391-405.

Maudos, J. and J. De Guevara. 2004. "Factors explaining the interest margin in the banking sectors of the European Union". Journal of Banking and Finance. Vol. 28(9): 2259-2281. 
McShane, R. and I. Sharpe. 1985. "A time series-cross section analysis of the determinants of Australian trading bank loan-deposit interest margins: 1962-1981". Journal of Banking and Finance, Vol. 9(1): 115-36.

Martinez Peria, M.S. and A. Mody. 2004. "How foreign participation and market concentration impact bank spreads: Evidence from Latin America". Journal of Money, Credit and Banking, Vol. 36(3), 511-537.

Nassar, K., E. Martinez and A. Pineda. 2014. "Determinants of banks' net interest margins in Honduras". IMF Working Paper. No. 14/163.

Park, H., Jun, H. and D. Lee. 2015. "Evaluation on the usefulness of the loan-to-deposit ratio regulation - From the macro-prudential policy perspective". Bank of Korea.

Perez, P. 2011. "Determinants of interest rate spreads in Belize". Research Staff Working Papers. Central of Belize: Belize City.

Randall, R. 1998, "Interest Rate Spreads in the Eastern Caribbean". IMF Working Paper. No. 98/59.

Saunders, A. and L. Schumacher. 2000. "The determinants of bank interest rate margins: An international study". Journal of International Money and Finance, Vol. 19, 813-832.

Valverde, S. and F. Fernández. 2007. "The determinants of bank margins in European banking". Journal of Banking and Finance. Vol. 31(7): 2043 - 2063.

Vander Vennet, R. 2002. "Cost and profit efficiency of financial conglomerates and universal banks in Europe". Journal of Money, Credit and Banking. Vol. 34: 254-282.

Williams, B. 2007. "Factors determining net interest margins in Australia: Domestic and foreign banks". Financial Markets, Institutions and Instruments. Vol. 16(3): 145-165. 


\section{Figures and Tables}

\section{Figure 1: Interest rates in selected banking regions (1998-2014)}

The figures on the left provide information on the loan, deposit and inflation rates. The loan rate is defined as the ratio of interest income to total loans and the deposit rate as the ratio of interest expenses to total deposits. The figures on the right show the $25^{\text {th }}, 50^{\text {th }}$ (median) and $75^{\text {th }}$ percentiles of the distribution of interest margins. The figures reported for the "Advanced Economies" are based on a sample of 105 major banks from the G10 countries plus Austria, Australia, and Spain (Brei and Gambacorta, 2016). The interest rates, margins and inflation rates are reported in percentage points. All values are unweighted averages across banks and countries.

Sources: BankScope, IMF-IFS and authors' own calculations.

\section{Caribbean}
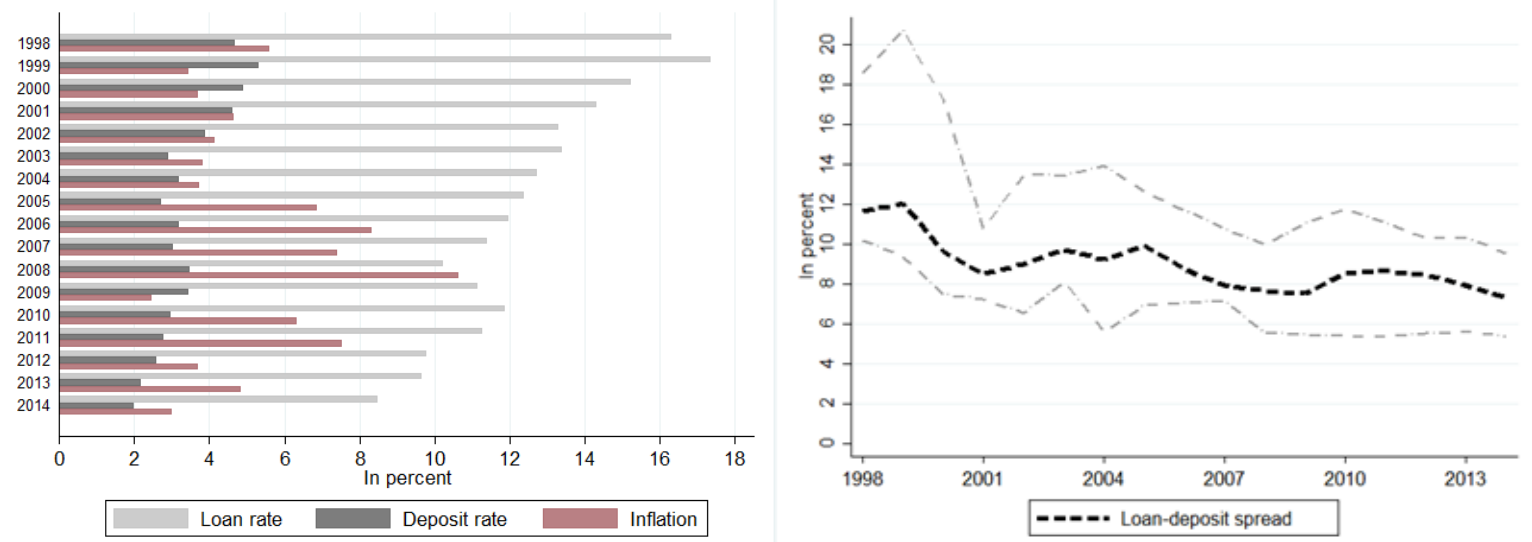

Central America
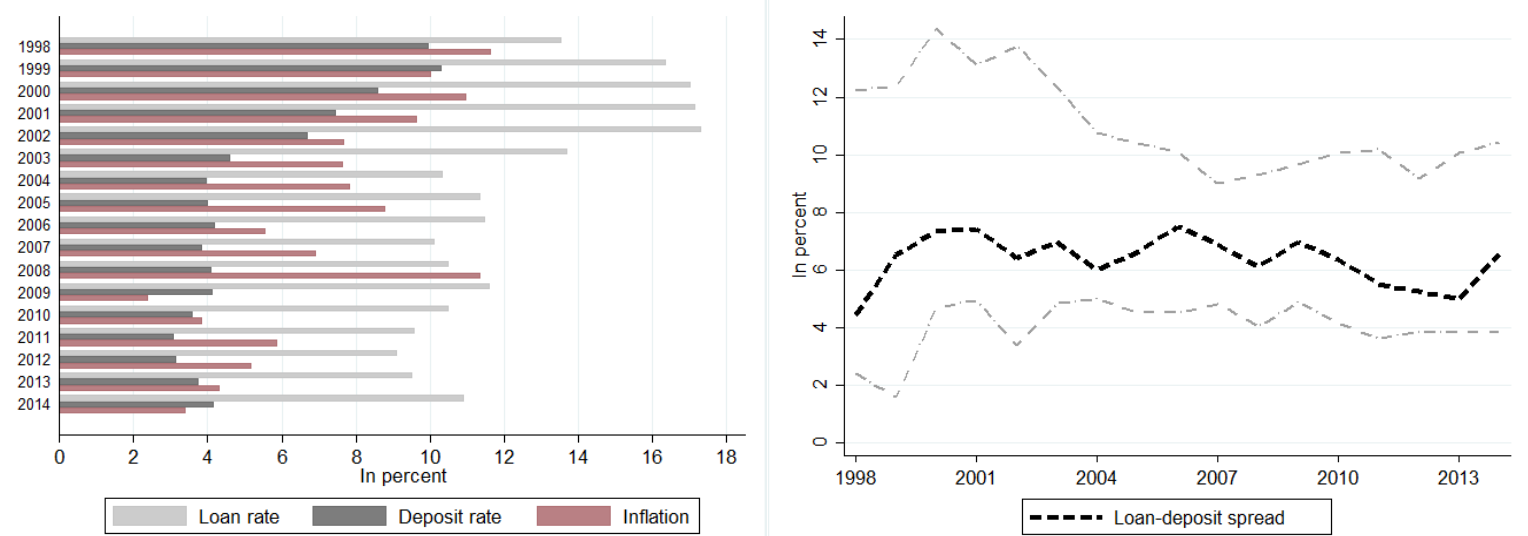

Advanced Economies
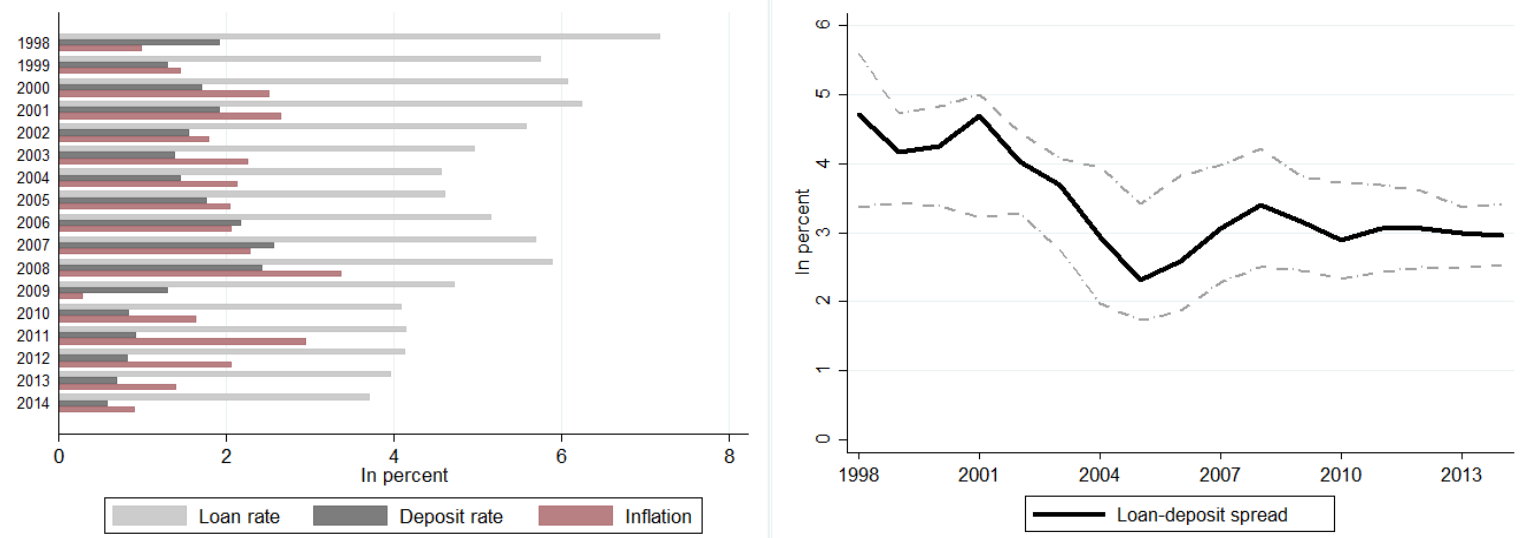
Figure 2: Performance indicators for the banking sector (1998-2014)

"Bank market power" is measured by the Lerner index and "Cost efficiency" by banks' operating costs over total assets. Non-performing loans divided by total loans and liquid assets divided by total assets are used as proxies for "Credit risk" and "Liquidity risk". "Interest rate risk" is measured by the standard deviation of the monthly lending rate using a 24 months rolling window. All values are unweighted averages across banks and countries. Sources: BankScope, IMF-IFS and authors' own calculations.

Bank market power

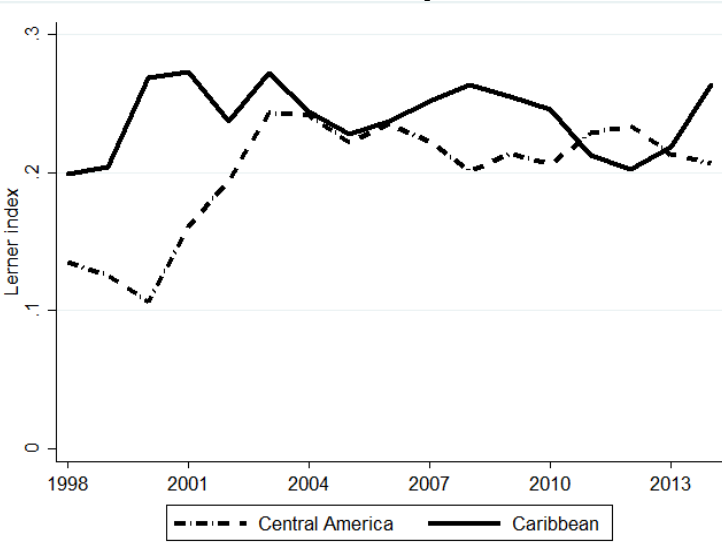

Credit risk

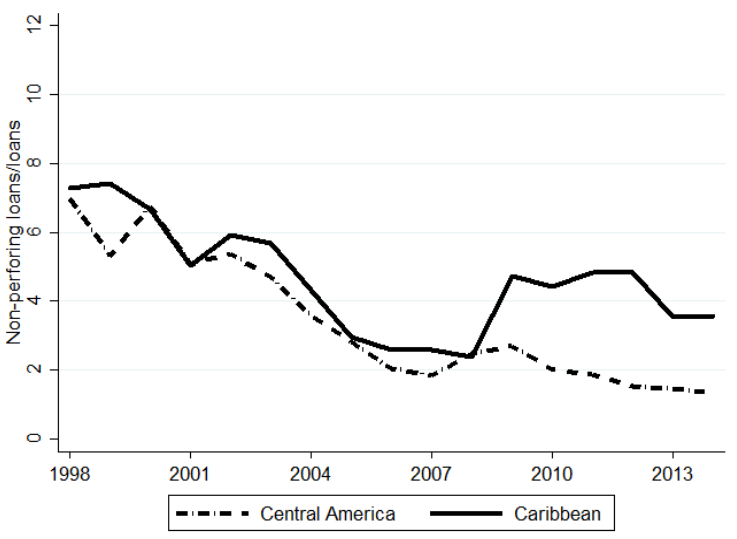

Non-interest income

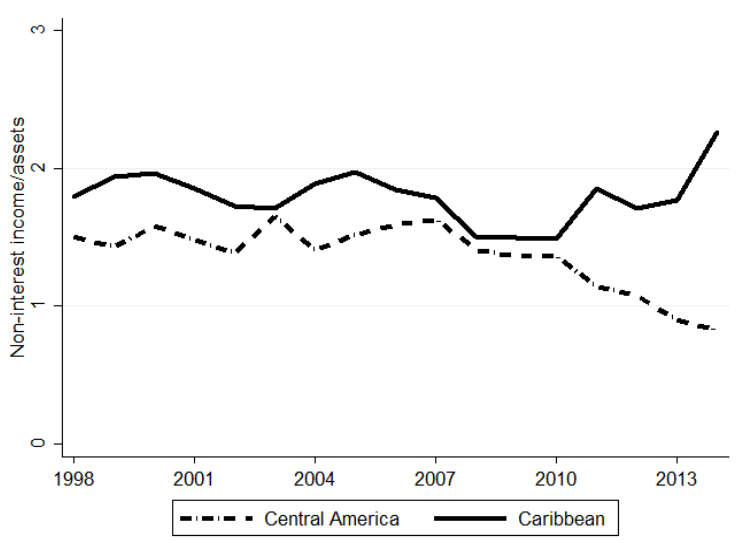

Cost efficiency

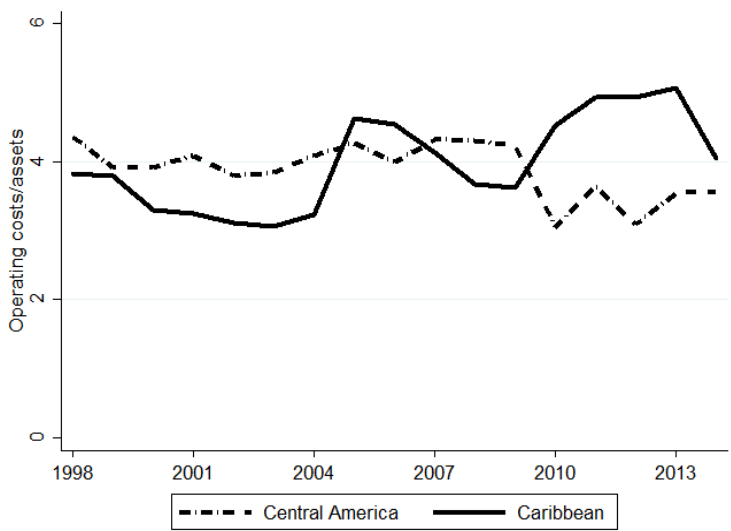

Liquidity risk

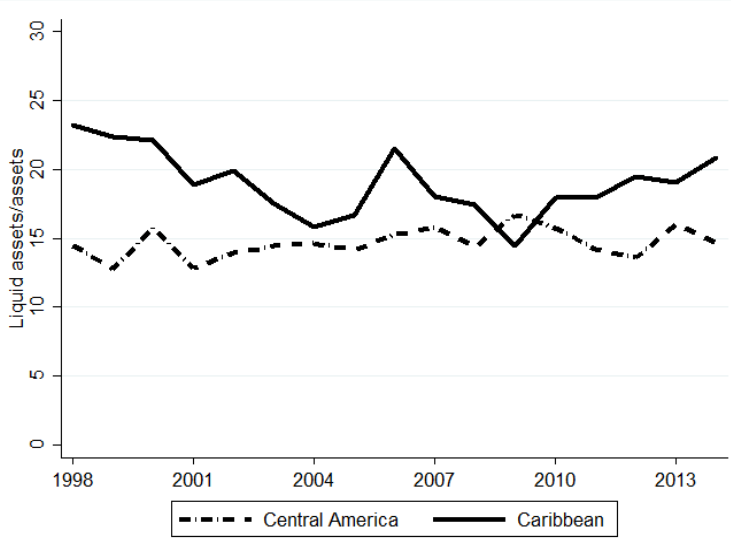

Interest rate risk

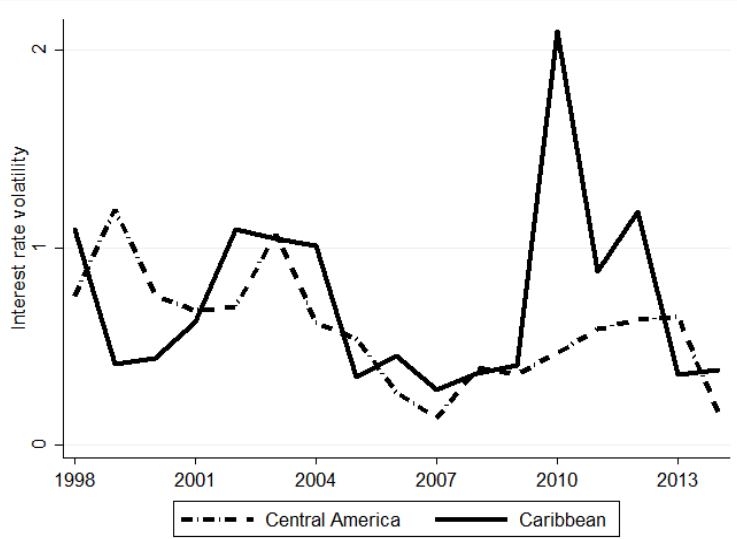




\section{Table 1: Macroeconomic statistics for selected countries}

The table provides information on the macroeconomic statistics for the sample countries. "Banks" denotes the total number of deposit-taking institutions (domestic and foreignowned) in a particular country. This figure excludes offshore and non-bank financial firms. "Bank entry requirements" is an index that ranges from 0 to 8 and higher the index value indicates greater stringency. "Reporting transparency" is an index on a scale of 0-6 and a higher value of the index indicates higher level of reporting transparency. "CPI inflation" denotes the annual inflation rate. Where applicable, unweighted averages over the period 1998-2014 are reported.

Sources: BankScope; IMF-IFS; Barth et al. (2013a); Claessens and von Horen (2015); authors' own calculations.

\begin{tabular}{|c|c|c|c|c|c|c|c|c|c|}
\hline & Banks & $\begin{array}{c}\text { Foreign } \\
\text { banks }\end{array}$ & $\begin{array}{c}\text { GDP } \\
(2014, \text { USD bn.) }\end{array}$ & $\begin{array}{c}\text { Total assets } \\
\text { (2014, USD bn.) }\end{array}$ & $\begin{array}{l}\text { Total assets } \\
\text { (2014, \% GDP) }\end{array}$ & $\begin{array}{l}\text { Real GDP } \\
\text { growth }\end{array}$ & $\begin{array}{c}\text { CPI } \\
\text { inflation }\end{array}$ & $\begin{array}{l}\text { Bank entry } \\
\text { requirements }\end{array}$ & $\begin{array}{c}\text { Reporting } \\
\text { transparency }\end{array}$ \\
\hline Anguilla & 1 & 0 & 0.2 & 0.4 & 211.5 & 4.5 & 4.2 & 8.0 & 3.7 \\
\hline Antigua \& Barbuda & 1 & 0 & 1.2 & 0.4 & 29.6 & -1.1 & 2.5 & 8.0 & 3.0 \\
\hline Aruba & 2 & 1 & 2.5 & 1.4 & 57.8 & 1.5 & 3.0 & 8.0 & 4.0 \\
\hline Belize & 1 & 1 & 1.1 & 0.5 & 43.4 & 7.2 & 1.9 & 8.0 & 3.0 \\
\hline Costa Rica & 17 & 5 & 46.6 & 36.9 & 79.2 & 4.4 & 8.9 & 7.3 & 5.0 \\
\hline Dominican Republic & 12 & 1 & 58.9 & 24.8 & 42.2 & 5.4 & 5.9 & 8.0 & 5.0 \\
\hline Grenada & 3 & 2 & 0.8 & 0.7 & 88.2 & 1.4 & 2.4 & 8.0 & 3.4 \\
\hline Guatemala & 16 & 9 & 57.2 & 32.6 & 57.1 & 3.4 & 5.7 & 7.6 & 3.4 \\
\hline Guyana & 3 & 1 & 3.1 & 1.4 & 43.1 & 2.6 & 5.2 & 7.7 & 5.0 \\
\hline Honduras & 18 & 9 & 18.3 & 14.4 & 78.7 & 3.8 & 7.2 & 8.0 & 3.8 \\
\hline Jamaica & 10 & 6 & 14.5 & 12.3 & 84.7 & 0.3 & 10.6 & 8.0 & 5.7 \\
\hline Panama & 35 & 17 & 42.8 & 106.7 & 249.3 & 6.9 & 3.6 & 8.0 & 4.2 \\
\hline Saint Kitts \& Nevis & 2 & 0 & 0.8 & 1.3 & 167.2 & 2.2 & 3.3 & 8.0 & 4.0 \\
\hline Saint Lucia & 5 & 1 & 1.2 & 2.6 & 224.3 & 1.5 & 2.6 & 8.0 & 3.5 \\
\hline St Vincent \& Grenadines & 1 & 0 & 0.7 & 0.3 & 44.6 & 1.4 & 5.8 & 8.0 & 3.0 \\
\hline Suriname & 1 & 0 & 2.9 & 0.3 & 9.9 & 4.4 & 8.9 & 8.0 & 4.0 \\
\hline Trinidad \& Tobago & 6 & 4 & 22.1 & 22.8 & 102.9 & 5.2 & 6.3 & 6.1 & 4.9 \\
\hline Total*/Average & $134^{*}$ & $57^{*}$ & 16.2 & 15.3 & 94.9 & 3.2 & 5.2 & 7.8 & 4.0 \\
\hline
\end{tabular}


Table 2: Market structure indices for selected regional banking sectors

"Bank entry requirements" is an index that ranges from 0 to 8 and a higher index value indicates greater stringency. "Foreign bank market share" is the share (reported as a percentage) of the banking system's assets in the respective region that is owned by foreign banks. "Reporting transparency" is an index on a scale of $0-6$ and a higher value of the index indicates higher level of reporting transparency. The sample includes 175 countries. All values for the reported regions are unweighted averages across countries over the years 1999, 2003, 2007 and 2011.

Sources: Barth et al. (2013a) and authors' own calculations.

\begin{tabular}{lccc}
\hline \hline & $\begin{array}{c}\text { Bank entry } \\
\text { requirements }\end{array}$ & $\begin{array}{c}\text { Foreign bank market } \\
\text { share }\end{array}$ & $\begin{array}{c}\text { Reporting } \\
\text { transparency }\end{array}$ \\
\hline Africa & 7.8 & 50.4 & 4.6 \\
Caribbean & 7.8 & 53.8 & 4.0 \\
Central America & 7.7 & 28.8 & 4.4 \\
Central Asia & 7.3 & 20.6 & 4.8 \\
Middle East & 7.5 & 23.7 & 5.5 \\
North America & 7.9 & 8.8 & 5.4 \\
South America & 7.4 & 38.0 & 4.9 \\
South-East Asia & 7.6 & 45.7 & 5.0 \\
Advanced Europe & 7.4 & 27.5 & 5.1 \\
Emerging Europe & 7.7 & 51.5 & 4.6 \\
\hline World average & $\mathbf{7 . 6}$ & $\mathbf{3 4 . 9}$ & $\mathbf{4 . 8}$ \\
\hline \hline
\end{tabular}




\section{Table 3: Banking sector summary statistics for selected countries}

The table provides summary statistics for the banking sector of the sampled countries. "NPL" denotes non-performing loans and "ROA" return on assets. The balance sheet indicators are divided by total assets with the exception of NPL which are divided by total loans. All values are reported in percentages and are unweighted averages across banks over the period 1998-2014. The figures reported for the "Advanced Economies" are based on a sample of 105 major banks from the G10 countries plus Austria, Australia, and Spain (Brei and Gambacorta, 2016).

\begin{tabular}{|c|c|c|c|c|c|c|c|c|c|c|}
\hline & Loan rate & $\begin{array}{c}\text { Deposit } \\
\text { rate }\end{array}$ & $\begin{array}{l}\text { Interest } \\
\text { margin }\end{array}$ & $\begin{array}{l}\text { Operating } \\
\text { costs }\end{array}$ & $\begin{array}{l}\text { Liquid } \\
\text { assets }\end{array}$ & NPL & ROA & $\begin{array}{l}\text { Total } \\
\text { loans }\end{array}$ & $\begin{array}{c}\text { Equity } \\
\text { ratio }\end{array}$ & $\begin{array}{l}\text { Lending } \\
\text { rate } \\
\text { volatility }\end{array}$ \\
\hline Anguilla & 9.8 & 2.8 & 7.0 & 2.5 & 22.0 & 12.4 & 1.0 & 60.8 & 8.2 & 0.3 \\
\hline Antigua \& Barbuda & 9.1 & 3.5 & 5.6 & 2.9 & 16.3 & 6.7 & 1.4 & 64.1 & 15.4 & 0.3 \\
\hline Aruba & 10.5 & 3.2 & 7.3 & 4.4 & 21.4 & 9.5 & 1.8 & 67.6 & 9.6 & 0.9 \\
\hline Belize & 14.9 & 9.2 & 5.7 & 2.9 & 19.0 & 3.9 & 6.4 & 72.1 & 14.3 & 0.3 \\
\hline Costa Rica & 12.3 & 7.6 & 4.7 & 4.8 & 14.1 & 5.2 & 1.4 & 62.8 & 12.8 & 1.7 \\
\hline Dominican Republic & 17.0 & 5.6 & 11.4 & 7.3 & 19.3 & 2.3 & 1.9 & 57.0 & 13.7 & 2.7 \\
\hline Grenada & 10.1 & 2.9 & 7.2 & 3.9 & 13.9 & 6.3 & 0.9 & 61.9 & 10.3 & 0.4 \\
\hline Guatemala & 20.0 & 5.7 & 14.3 & 6.4 & 16.2 & 3.5 & 1.3 & 58.1 & 10.3 & 0.4 \\
\hline Guyana & 12.8 & 2.8 & 10.0 & 3.2 & 20.6 & 18.0 & 1.4 & 36.1 & 9.3 & 0.3 \\
\hline Honduras & 18.6 & 5.7 & 12.9 & 6.5 & 14.1 & 4.6 & 1.1 & 61.3 & 14.2 & 0.8 \\
\hline Jamaica & 19.6 & 4.9 & 14.7 & 5.6 & 17.4 & 5.4 & 1.5 & 37.7 & 14.2 & 0.9 \\
\hline Panama & 8.4 & 3.5 & 4.9 & 2.5 & 17.5 & 2.2 & 1.4 & 62.9 & 10.5 & 0.4 \\
\hline Saint Kitts \& Nevis & 11.0 & 3.2 & 7.8 & 2.4 & 29.8 & 8.4 & 1.6 & 39.3 & 12.8 & 0.4 \\
\hline Saint Lucia & 10.1 & 3.6 & 6.5 & 3.1 & 18.4 & 18.3 & 1.0 & 60.2 & 11.5 & 0.5 \\
\hline St Vincent \& Grenadines & 8.8 & 2.9 & 5.9 & 3.5 & 11.7 & 2.4 & 1.5 & 69.8 & 10.4 & 0.2 \\
\hline Suriname & 10.8 & 2.4 & 8.4 & 4.2 & 40.6 & 2.0 & -1.0 & 52.4 & 5.5 & 1.2 \\
\hline Trinidad \& Tobago & 11.9 & 4.6 & 7.3 & 3.5 & 18.2 & 3.6 & 2.2 & 50.1 & 13.9 & 0.8 \\
\hline Average & 12.7 & 4.4 & 8.3 & 4.1 & 19.4 & 6.7 & 1.6 & 57.3 & 11.6 & 0.7 \\
\hline Advanced economies & 5.7 & 2.0 & 3.7 & 2.1 & 14.0 & 3.5 & 0.6 & 55.5 & 6.0 & 0.4 \\
\hline
\end{tabular}

Sources: BankScope; IMF-IFS and authors' own calculations. 
Table 4: Summary statistics for the regression variables

The sample period goes from 1998 to 2014. "Unit" denotes the measurement unit of the model's variables. "Obs." denotes the number of observation for the respective variable. Columns 4-7 denote the mean, standard deviation, minimum and maximum, respectively.

\begin{tabular}{lcccccc}
\hline \hline Variable & Unit & Obs. & Mean & Std. Dev. & Min & Max \\
\hline Spread without fees & Percentage & 1,016 & 8.55 & 8.09 & -38.69 & 86.40 \\
Spread with net fees & Percentage & 1,016 & 9.41 & 7.84 & -35.97 & 87.94 \\
Lerner index & Index & 1,016 & 0.23 & 0.13 & 0.00 & 0.84 \\
Operating costs/total assets & Percentage & 1,016 & 4.51 & 3.19 & 0.27 & 34.15 \\
NPL/ loans & Percentage & 1,016 & 4.90 & 6.50 & 0.02 & 75.27 \\
Liquid assets/total assets & Percentage & 1,016 & 16.88 & 7.86 & 1.94 & 60.28 \\
Non-interest income/total assets & Percentage & 1,016 & 1.62 & 1.58 & -9.95 & 17.68 \\
Loans/deposits & Percentage & 1,016 & 89.28 & 42.10 & 13.57 & 429.37 \\
Equity/total assets & Percentage & 1,016 & 11.90 & 5.63 & 0.54 & 83.03 \\
Real GDP growth & Percentage & 1,016 & 4.19 & 3.71 & -18.41 & 20.28 \\
Inflation & Percentage & 1,016 & 6.06 & 3.60 & -1.67 & 22.02 \\
Standard deviation, loan rate & Percentage & 1,016 & 0.84 & 0.87 & 0.00 & 5.33 \\
Bank entry requirements & Index & 1,016 & 7.68 & 0.97 & 3.00 & 8.00 \\
Foreign bank share & Percentage & 1,016 & 39.14 & 25.68 & 1.60 & 95.20 \\
Bank transparency & Index & 1,016 & 4.34 & 1.01 & 2.00 & 6.00 \\
\hline \hline
\end{tabular}




\section{Table 5: Regression results}

The sample period goes from 1998 to 2014. The number of banks is 134 and the number of observations is 1,016 . All estimations are based on the Arellano and Bover (1995) system GMM estimator. Robust standard errors are reported in brackets. The null hypothesis of the AR2 test is that errors in the first-difference regression exhibit no second-order serial correlation. The null hypothesis of the Hansen test is that the instruments are valid. ${ }^{* *},{ }^{* *}$, ${ }^{*}$ indicate significance at the $1 \%, 5 \%$, and $10 \%$ level, respectively.

\begin{tabular}{|c|c|c|c|c|c|c|}
\hline & \multicolumn{3}{|c|}{ Spread without net fees } & \multicolumn{3}{|c|}{ Spread with net fees } \\
\hline & [1] & [2] & [3] & [4] & [5] & [6] \\
\hline Spread, t-1 & $\begin{array}{l}0.573^{* \star \star} \\
(0.072)\end{array}$ & $\begin{array}{l}0.565^{* * *} \\
(0.074)\end{array}$ & $\begin{array}{l}0.550^{* * *} \\
(0.076)\end{array}$ & $\begin{array}{l}0.503^{* \star *} \\
(0.113)\end{array}$ & $\begin{array}{l}0.514^{* \star *} \\
(0.111)\end{array}$ & $\begin{array}{l}0.495^{* * *} \\
(0.113)\end{array}$ \\
\hline Lerner index & $\begin{array}{l}7.643^{\star \star \star} \\
(2.448)\end{array}$ & $\begin{array}{l}8.027^{\star \star \star} \\
(2.525)\end{array}$ & $\begin{array}{l}8.242^{* \star \star} \\
(2.503)\end{array}$ & $\begin{array}{l}7.116^{\star * *} \\
(2.578)\end{array}$ & $\begin{array}{l}7.380^{\star \star *} \\
(2.562)\end{array}$ & $\begin{array}{l}7.611^{\star \star \star} \\
(2.574)\end{array}$ \\
\hline $\begin{array}{l}\text { Operating costs/total } \\
\text { assets }\end{array}$ & $\begin{array}{l}0.822^{* \star \star} \\
(0.173)\end{array}$ & $\begin{array}{l}0.821^{* * \star} \\
(0.189)\end{array}$ & $\begin{array}{l}0.831^{* * *} \\
(0.192)\end{array}$ & $\begin{array}{l}0.802^{* \star *} \\
(0.198)\end{array}$ & $\begin{array}{l}0.759^{* \star \star} \\
(0.189)\end{array}$ & $\begin{array}{l}0.768^{* * \star} \\
(0.189)\end{array}$ \\
\hline NPL/loans & $\begin{array}{l}0.099^{* *} \\
(0.044)\end{array}$ & $\begin{array}{l}0.090^{* *} \\
(0.045)\end{array}$ & $\begin{array}{l}0.088^{*} \\
(0.046)\end{array}$ & $\begin{array}{l}0.111^{*} \\
(0.062)\end{array}$ & $\begin{array}{l}0.103^{*} \\
(0.062)\end{array}$ & $\begin{array}{l}0.101^{*} \\
(0.063)\end{array}$ \\
\hline $\begin{array}{l}\text { Liquid assets/total } \\
\text { assets }\end{array}$ & $\begin{array}{l}0.088^{* *} \\
(0.040)\end{array}$ & $\begin{array}{l}0.092^{* *} \\
(0.040)\end{array}$ & $\begin{array}{l}0.090^{* *} \\
(0.040)\end{array}$ & $\begin{array}{l}0.058^{*} \\
(0.037)\end{array}$ & $\begin{array}{l}0.059^{*} \\
(0.034)\end{array}$ & $\begin{array}{l}0.054^{*} \\
(0.032)\end{array}$ \\
\hline $\begin{array}{l}\text { Non-interest } \\
\text { income/total assets }\end{array}$ & $\begin{array}{l}-0.628^{* \star \star} \\
(0.199)\end{array}$ & $\begin{array}{l}-0.771^{* \star *} \\
(0.219)\end{array}$ & $\begin{array}{l}-0.723^{* * *} \\
(0.221)\end{array}$ & $\begin{array}{l}-0.559^{*} \\
(0.297)\end{array}$ & $\begin{array}{l}-0.625^{* *} \\
(0.308)\end{array}$ & $\begin{array}{l}-0.536^{*} \\
(0.291)\end{array}$ \\
\hline Loans/deposits & $\begin{array}{l}-0.008 \\
(0.011)\end{array}$ & $\begin{array}{l}-0.009 \\
(0.012)\end{array}$ & $\begin{array}{l}-0.010 \\
(0.012)\end{array}$ & $\begin{array}{l}-0.021 \\
(0.015)\end{array}$ & $\begin{array}{l}-0.021 \\
(0.015)\end{array}$ & $\begin{array}{l}-0.023 \\
(0.016)\end{array}$ \\
\hline Equity/total assets & $\begin{array}{l}-0.061 \\
(0.065)\end{array}$ & $\begin{array}{l}-0.064 \\
(0.065)\end{array}$ & $\begin{array}{l}-0.061 \\
(0.063)\end{array}$ & $\begin{array}{c}0.046 \\
(0.078)\end{array}$ & $\begin{array}{c}0.050 \\
(0.075)\end{array}$ & $\begin{array}{c}0.057 \\
(0.071)\end{array}$ \\
\hline Real GDP growth & & $\begin{array}{l}-0.066^{* \star *} \\
(0.023)\end{array}$ & $\begin{array}{l}-0.068^{* * *} \\
(0.025)\end{array}$ & & $\begin{array}{l}-0.042 \\
(0.029)\end{array}$ & $\begin{array}{l}-0.044 \\
(0.030)\end{array}$ \\
\hline Inflation & & $\begin{array}{l}-0.041 \\
(0.057)\end{array}$ & $\begin{array}{l}-0.036 \\
(0.056)\end{array}$ & & $\begin{array}{c}0.001 \\
(0.059)\end{array}$ & $\begin{array}{c}0.014 \\
(0.060)\end{array}$ \\
\hline $\begin{array}{l}\text { Standard deviation, } \\
\text { loan rate }\end{array}$ & & $\begin{array}{l}0.294^{*} \\
(0.176)\end{array}$ & $\begin{array}{l}0.347^{*} \\
(0.209)\end{array}$ & & $\begin{array}{l}0.369^{*} \\
(0.216)\end{array}$ & $\begin{array}{l}0.442^{*} \\
(0.252)\end{array}$ \\
\hline $\begin{array}{l}\text { Bank entry } \\
\text { requirements }\end{array}$ & & & $\begin{array}{l}0.310^{*} \\
(0.162)\end{array}$ & & & $\begin{array}{l}0.427^{* *} \\
(0.196)\end{array}$ \\
\hline Foreign bank share & & & $\begin{array}{l}-0.010^{*} \\
(0.005)\end{array}$ & & & $\begin{array}{l}-0.013^{* *} \\
(0.005)\end{array}$ \\
\hline Bank transparency & & & $\begin{array}{l}-0.217^{* *} \\
(0.102)\end{array}$ & & & $\begin{array}{l}-0.270^{* *} \\
(0.114)\end{array}$ \\
\hline Constant & $\begin{array}{l}4.301^{* * *} \\
(0.728)\end{array}$ & $\begin{array}{l}4.643^{* * \star} \\
(0.912)\end{array}$ & $\begin{array}{l}3.659^{* * *} \\
(1.355)\end{array}$ & $\begin{array}{l}5.365^{* * *} \\
(1.209)\end{array}$ & $\begin{array}{l}5.035^{* * *} \\
(1.156)\end{array}$ & $\begin{array}{l}3.541^{* *} \\
(1.727)\end{array}$ \\
\hline Hansen ( $p$-value) & 0.32 & 0.19 & 0.27 & 0.19 & 0.28 & 0.38 \\
\hline AR2 (p-value) & 0.87 & 0.96 & 0.96 & 0.59 & 0.53 & 0.51 \\
\hline
\end{tabular}




\section{Table 6: Economic significance of the loan-deposit spread determinants}

This table reports short- and long-term implied elasticities of the significant determinants in the model specifications [3] and [6], respectively, shown in Table 5. The implied elasticities indicate the percent variation of the interest margin in response to a $10 \%$ increase in its determinant evaluated at the mean values of the sample. The short-term elasticity between the margin $Y$ and determinant $X$ is calculated by $\varepsilon_{X}^{Y}=\frac{\partial Y / \bar{Y}}{\partial X / \bar{X}}=\beta \frac{\bar{X}}{\bar{Y}}$ and the long-term elasticity by $\varepsilon_{X}^{Y} /\left(1-\alpha_{1}\right)$, where $\alpha_{1}$ is the autoregressive coefficient of the margin and $\beta$ the coefficient of variable $X$.

\begin{tabular}{l|cccc}
\hline \multirow{2}{*}{ Determinant } & \multicolumn{2}{c}{$\begin{array}{c}\text { Spread without net fees } \\
\text { Short-term }\end{array}$} & $\begin{array}{c}\text { Spread with net fees } \\
\text { Long-term }\end{array}$ & $\begin{array}{c}\text { Short-term } \\
\text { Long-term }\end{array}$ \\
\hline Lerner index & 2.3 & 5.0 & 2.1 & 4.1 \\
Operating costs/total assets & 4.4 & 9.7 & 4.0 & 8.0 \\
NPL/loans & 0.5 & 1.1 & 0.3 & 0.6 \\
Liquid assets/total assets & 1.7 & 3.8 & 2.0 & 3.9 \\
Non-interest income/total assets & -1.3 & -3.0 & -1.0 & -2.0 \\
Real GDP growth & -0.3 & -0.7 & -0.2 & -0.4 \\
Standard deviation, loan rate & 0.3 & 0.8 & 0.4 & 0.9 \\
Bank entry requirements & 2.8 & 6.2 & 3.8 & 7.6 \\
Foreign bank share & -0.4 & -1.0 & -0.6 & -1.2 \\
Bank transparency & -1.1 & -2.4 & -1.4 & -2.7 \\
\hline \hline
\end{tabular}


Table 7: Robustness tests

The sample period goes from 1998 to 2014. In specification 7, the number of banks is 124 and the number of observations is 923 , while in specifications 8-12 the number of banks is 134 and the number of observations is 1,016 . All estimations are based on the Arellano and Bover (1995) system GMM estimator. Robust standard errors are reported in brackets. The null hypothesis of the AR2 test is that errors in the first-difference regression exhibit no second-order serial correlation. The null hypothesis of the Hansen test is that the instruments are valid. ***, **, * indicate significance at the $1 \%, 5 \%$, and $10 \%$ level, respectively.

\begin{tabular}{|c|c|c|c|c|c|c|}
\hline & \multicolumn{4}{|c|}{ Spread with net fees } & \multirow{2}{*}{$\begin{array}{c}\text { Loan rate } \\
{[11]}\end{array}$} & \multirow{2}{*}{$\begin{array}{c}\text { Deposit rate } \\
\text { [12] }\end{array}$} \\
\hline & [7] & [8] & [9] & [10] & & \\
\hline $\mathrm{Y}, \mathrm{t}-1$ & $0.486^{* * *}$ & $0.496^{* * *}$ & $0.494^{* * *}$ & $0.496^{* * *}$ & $0.661^{* * *}$ & $0.465^{* * *}$ \\
\hline & $\begin{array}{l}(0.113) \\
7.008^{* * *}\end{array}$ & $\begin{array}{l}(0.112) \\
6.875^{*}\end{array}$ & $\begin{array}{l}(0.112) \\
6.831^{* * t}\end{array}$ & $\begin{array}{l}(0.115) \\
7.626^{* \star \star}\end{array}$ & $\begin{array}{l}(0.051) \\
5.593^{\star * *}\end{array}$ & $\begin{array}{l}(0.063)^{\star} \\
-4.034^{\star *}\end{array}$ \\
\hline Lerner Index & $(2.527)$ & $(2.794)$ & $(2.600)$ & $(2.630)$ & $(1.895)$ & $(1.693)$ \\
\hline Operating costs/total assets & $\begin{array}{l}0.769^{k * \star} \\
(0.188)\end{array}$ & $\begin{array}{l}0.756^{* * *} \\
(0.184)\end{array}$ & $\begin{array}{l}0.723^{* * *} \\
(0.191)\end{array}$ & $\begin{array}{l}0.756^{* * *} \\
(0.192)\end{array}$ & $\begin{array}{l}0.656^{\star * \star} \\
(0.120)\end{array}$ & $\begin{array}{l}-0.056 \\
(0.074)\end{array}$ \\
\hline NPL/loans & 0.115 & 0.106 & $0.116^{*}$ & 0.109 & 0.056 & -0.041 \\
\hline & $\begin{array}{l}(0.098) \\
0.0529\end{array}$ & $\begin{array}{l}(0.065) \\
0.055^{*}\end{array}$ & $\begin{array}{l}(0.066) \\
0.054^{\star}\end{array}$ & $\begin{array}{l}(0.069) \\
0.057^{\star}\end{array}$ & $\begin{array}{c}(0.044) \\
0.043\end{array}$ & $\begin{array}{l}(0.031) \\
-0.024\end{array}$ \\
\hline Liquid assets/total assets & $\begin{array}{l}(0.034) \\
-0.471^{*}\end{array}$ & $\begin{array}{l}(0.033) \\
-0.555^{*}\end{array}$ & $\begin{array}{l}(0.030) \\
-0.559^{*}\end{array}$ & $\begin{array}{l}(0.034) \\
-0.522^{*}\end{array}$ & $\begin{array}{l}(0.035) \\
-0.665^{* \star}\end{array}$ & $\begin{array}{l}(0.024) \\
-0.142\end{array}$ \\
\hline Non-interest inc./total assets & $(0.276)$ & $(0.306)$ & $(0.298)$ & $(0.294)$ & $(0.208)$ & $(0.094)$ \\
\hline Loans/deposits & $\begin{array}{l}-0.024 \\
(0.016)\end{array}$ & $\begin{array}{l}-0.023 \\
(0.016)\end{array}$ & $\begin{array}{l}-0.023 \\
(0.016)\end{array}$ & $\begin{array}{l}-0.022 \\
(0.015)\end{array}$ & $\begin{array}{l}0.008^{*} \\
(0.004)\end{array}$ & $\begin{array}{c}0.016 \\
(0.012)\end{array}$ \\
\hline Equity/total assets & $\begin{array}{c}0.064 \\
(0.073)\end{array}$ & $\begin{array}{c}0.068 \\
(0.078)\end{array}$ & $\begin{array}{c}0.072 \\
(0.076)\end{array}$ & $\begin{array}{c}0.054 \\
(0.074)\end{array}$ & $\begin{array}{c}0.021 \\
(0.036)\end{array}$ & $\begin{array}{l}0.111^{*} \\
(0.058)\end{array}$ \\
\hline Real GDP growth & $\begin{array}{l}-0.076^{*} \\
(0.039)\end{array}$ & $\begin{array}{l}-0.042 \\
(0.030)\end{array}$ & $\begin{array}{l}-0.037 \\
(0.031)\end{array}$ & $\begin{array}{l}-0.045 \\
(0.030)\end{array}$ & $\begin{array}{c}-0.106^{* * t} \\
(0.029)\end{array}$ & $\begin{array}{l}-0.067^{* *} \\
(0.030)\end{array}$ \\
\hline Inflation & $\begin{array}{l}-0.001 \\
(0.065)\end{array}$ & $\begin{array}{c}0.014 \\
(0.060)\end{array}$ & $\begin{array}{c}0.011 \\
(0.059)\end{array}$ & $\begin{array}{c}0.007 \\
(0.060)\end{array}$ & $\begin{array}{l}0.057^{*} \\
(0.033)\end{array}$ & $\begin{array}{l}0.108^{* *} \\
(0.044)\end{array}$ \\
\hline Standard deviation, loan rate & $\begin{array}{c}0.423 \\
(0.269)\end{array}$ & $\begin{array}{l}0.443^{*} \\
0253)\end{array}$ & $0.486^{*}$ & $0.487^{*}$ & 0.052 & -0.199 \\
\hline Bank entry requirements & $\begin{array}{l}0.449^{* *} \\
(0.211)\end{array}$ & $\begin{array}{l}(0.253) \\
0.440^{* *} \\
(0.201)\end{array}$ & $\begin{array}{l}0.468^{\star *} \\
(0.205)\end{array}$ & $\begin{array}{l}(0.255)^{* * *} \\
0.559^{* *} \\
(0.216)\end{array}$ & $\begin{array}{l}(0.130)^{* * *} \\
0.290^{* *} \\
(0.081)\end{array}$ & $\begin{array}{l}(0.145) \\
-0.064 \\
(0.210)\end{array}$ \\
\hline Foreign bank share & $\begin{array}{l}-0.010^{*} \\
(0.006)\end{array}$ & $\begin{array}{l}-0.013^{* *} \\
(0.005)\end{array}$ & $\begin{array}{l}-0.015^{k+*} \\
(0.006)\end{array}$ & $\begin{array}{l}-0.017^{*} \\
(0.011)\end{array}$ & $\begin{array}{c}-0.019^{* * *} \\
(0.005)\end{array}$ & $\begin{array}{l}-0.016^{* * *} \\
(0.004)\end{array}$ \\
\hline Bank transparency & $\begin{array}{c}-0.391^{* \star \star} \\
(0.114)\end{array}$ & $\begin{array}{c}-0.283^{* \star \star} \\
(0.104)\end{array}$ & $\begin{array}{l}-0.247^{* *} \\
(0.121)\end{array}$ & $\begin{array}{c}-0.397^{\star \star *} \\
(0.135)\end{array}$ & $\begin{array}{l}-0.223^{* *} \\
(0.095)\end{array}$ & $\begin{array}{l}-0.027 \\
(0.083)\end{array}$ \\
\hline Economic freedom & $\begin{array}{c}0.001 \\
(0.050)\end{array}$ & & & & & \\
\hline Bank size & & $\begin{array}{c}0.065 \\
(0.200)\end{array}$ & & & & \\
\hline Foreign bank dummy & & & $\begin{array}{l}0.785^{\star} \\
(0.454)\end{array}$ & & & \\
\hline Bank entry requirem. ${ }^{*}$ Carib. & & & & $\begin{array}{l}-0.196 \\
(0.140)\end{array}$ & & \\
\hline Foreign bank share*Carib. & & & & $\begin{array}{c}0.007 \\
(0.014)\end{array}$ & & \\
\hline Bank transparency ${ }^{\star}$ Carib. & & & & $\begin{array}{c}0.297 \\
(0.239)\end{array}$ & & \\
\hline Constant & $\begin{array}{c}4.243 \\
(3.935) \\
\end{array}$ & $\begin{array}{l}3.474^{* *} \\
(1.741)\end{array}$ & $\begin{array}{r}2.825 \\
(1.797) \\
\end{array}$ & $\begin{array}{c}3.184^{*} \\
(1.678)\end{array}$ & $\begin{array}{l}4.227^{* \star *} \\
(1.146)\end{array}$ & $\begin{array}{c}3.393^{*} \\
(1.757) \\
\end{array}$ \\
\hline Hansen ( $p$-value) & 0.49 & 0.37 & 0.35 & 0.37 & 0.23 & 0.69 \\
\hline AR2 ( $p$-value) & 0.49 & 0.51 & 0.52 & 0.51 & 0.61 & 0.67 \\
\hline
\end{tabular}

